\title{
Study of knowledge, attitude, practices regarding PPIUCD among antenatal women at a tertiary care centre in Northern India
}

\author{
Mona Asnani*, Anjoo Agarwal, Renu Singh
}

Department of Obstetrics and Gynecology, KGMU, Lucknow, Uttar Pradesh, India

Received: 01 January 2019

Accepted: 05 February 2019

*Correspondence:

Dr. Mona Asnani,

E-mail: drkanakdarshanbajaj@gmail.com

Copyright: () the author(s), publisher and licensee Medip Academy. This is an open-access article distributed under the terms of the Creative Commons Attribution Non-Commercial License, which permits unrestricted non-commercial use, distribution, and reproduction in any medium, provided the original work is properly cited.

\begin{abstract}
Background: PPIUCD has been introduced in the national family welfare program since March 2010 in several states. AN IUCD can be inserted in 48 hours postpartum, referred to here as postpartum intrauterine contraceptive device. This study was done to assess the Knowledge, attitude and practice of postpartum Intrauterine contraceptive device in antenatal patients at a tertiary care centre in Northern India.

Methods: This is a questionnaire based cross sectional observational study including 350 antenatal women attending antenatal OPD over a period of 6 months.

Results: Out of these 350 women, 126 women (36\%) had knowledge of PPIUCD. only $30 \%$ of women had previous knowledge about PPIUCD however only $10 \%$ of women practiced it in the past. After appropriate counselling $18 \%$ of women agreed for insertion of PPIUCD after this delivery.

Conclusions: The study concludes that the antenatal women had poor knowledge regarding PPIUCD. Practices were even worse. This might be attributed to low education, refusal by family especially male partner, and religious beliefs. But once appropriate knowledge and information is provided, attitude gradually changes.
\end{abstract}

Keywords: Knowledge, PPIUCD, Practices

\section{INTRODUCTION}

In developing countries, about $61 \%$ of births occur at interval that is shorter than 36 months. More than 100 million women in developing countries would prefer to avoid a pregnancy but they may not be using any form of contraception. ${ }^{1}$

This may be due to poor knowledge of contraceptives, fear of side effects and inability to return for a contraceptive advice. PPIUCD has been introduced in the national family welfare program since March 2010 in several states. ${ }^{2}$ AN IUCD can be inserted in 48 hours postpartum, referred to here as postpartum intrauterine contraceptive device. ${ }^{3}$ Postpartum period is one of the important and crucial time when women and couples are more receptive and motivated for family planning methods. If a contraceptive is provided prior to discharge from the hospital, then the women or couple need not return specially for contraception.

The couple has been protected before they assume sexual activity. ${ }^{4}$ PPIUCD is associated with less discomfort, fewer side effects, lower incidence of infection, relief of overcrowded outpatient facilities, protection against unwanted pregnancy and consequent abortion. HIV positive women on antiretroviral therapy can also avail the benefit of PPIUCD.

Apart from this, it does not interfere with breastfeeding. ${ }^{5}$ In addition, complaints associated by IUCD insertion are masked by postnatal lochia and afterpains. ${ }^{6}$ The objective of the present study was to assess the Knowledge, attitude and practice of postpartum Intrauterine contraceptive 
device in antenatal patients at a tertiary care centre in northern india

\section{METHODS}

This is a cross sectional observational study including 350 antenatal women attending antenatal OPD over a period of 6 months from 1 January 2018 to 30 June 2018 in department of Obstetrics and Gynecology, KGMU, Lucknow.

\section{Inclusion criteria}

- Antenatal women attending ANC OPD in their $1^{\text {st }}$ antenatal visit irrespective of gestational age, willing to participate for the study, able to understand Hindi or English.

\section{Exclusion criteria}

- Women not giving consent for study

- Women not understanding Hindi and English.

All the women enrolled in the study were evaluated using a pre-designed questionnaire. Questionnaire was filled for each woman with help of resident doctor or intern doctor. women were assessed regarding knowledge of contraceptives and practices in past.

Women were provided with appropriate knowledge of postpartum Intrauterine contraceptive device insertion and its advantages. They were given the option of PPIUCD insertion after this delivery. Data was analysed by using frequency and percentage.

\section{RESULTS}

350 antenatal women attending the antenatal OPD at their first antenatal visit were included in the study. All the participants were evaluated regarding knowledge of contraceptive methods.

Out of these 350 women, 126 women (36\%) had knowledge of PPIUCD. Table 1 shows the demographic characteristics of individuals. Women who had prior knowledge regarding PPIUCD were maximum in age group of 25-35 years.

Table 1: Demographic characteristics.

\begin{tabular}{|l|l|l|l|}
\hline $\begin{array}{l}\text { Age } \\
\text { (years) }\end{array}$ & $\begin{array}{l}\text { No. of } \\
\text { women }\end{array}$ & $\begin{array}{l}\text { \% of } \\
\text { women }\end{array}$ & $\begin{array}{l}\text { No. of women having } \\
\text { knowledge of PPIUCD }\end{array}$ \\
\hline $18-25$ & 153 & 43.71 & $36(28.57 \%)$ \\
\hline $25-35$ & 120 & 34.28 & $54(42.85 \%)$ \\
\hline$>35$ & 77 & 22 & $36(28.57 \%)$ \\
\hline
\end{tabular}

Table 2 shows socioeconomic status of participating women. Maximum percentage of women having knowledge of PPIUCD were in upper middle class however the women belonging to upper middle class were very few.

Table 2: Socioeconomic status.

\begin{tabular}{|l|l|l|l|}
$\begin{array}{l}\text { Socioeconomic } \\
\text { status }\end{array}$ & $\begin{array}{l}\text { No. of } \\
\text { women }\end{array}$ & $\begin{array}{l}\text { \% of } \\
\text { women }\end{array}$ & $\begin{array}{l}\text { No. of women } \\
\text { having } \\
\text { knowledge of } \\
\text { PPIUCD }\end{array}$ \\
\hline Upper middle class & 10 & 2.85 & $10(100 \%)$ \\
\hline Lower middle class & 72 & 20.57 & $45(62.5 \%)$ \\
\hline Upper lower class & 98 & 28 & $42(42.85 \%)$ \\
\hline Lower class & 170 & 48.57 & $29(17.05 \%)$ \\
\hline
\end{tabular}

Table 3 shows that $43.71 \%$ of participating women were illiterate. Only $9.7 \%$ of these women had knowledge regarding PPIUCD.

Table 3: Educational status.

\begin{tabular}{|c|c|c|c|}
\hline Category & No. & $\%$ & $\begin{array}{l}\% \text { having } \\
\text { knowledge } \\
\text { of PPIUCD }\end{array}$ \\
\hline Illiterate & 153 & 43.71 & $8(5.22 \%)$ \\
\hline Below $10^{\text {th }}$ standard & 106 & 30.28 & $54(50.94 \%)$ \\
\hline $10-12^{\text {th }}$ standard & 52 & 14.86 & $33(63.46 \%)$ \\
\hline Graduate & 31 & 8.86 & $24(77.4 \%)$ \\
\hline Postgraduate and above & 8 & 2.28 & $7(87.5 \%)$ \\
\hline
\end{tabular}

Among the women participating in study $36.5 \%$ of women were primigravida. $63.5 \%$ of the women were multigravida. Most of women $(63.5 \%)$ participating in the study were multigravida (Table 4).

Table 4: Parity.

\begin{tabular}{|l|l|l|l|}
\hline Parity & $\begin{array}{l}\text { No. of } \\
\text { women }\end{array}$ & $\begin{array}{l}\text { \% of } \\
\text { women }\end{array}$ & $\begin{array}{l}\text { \% having } \\
\text { knowledge of } \\
\text { PPIUCD }\end{array}$ \\
\hline Primigravida & 128 & 36.5 & $48(37.5 \%)$ \\
\hline Multigravida & 222 & 63.5 & $78(35.13 \%)$ \\
\hline
\end{tabular}

About $62 \%$ of women had knowledge of barrier contraceptive but only $28 \%$ were practicing it. $54 \%$ of women had knowledge of IUCD but only $28 \%$ of them used it at least once in her life (Table 5). $45 \%$ women had knowledge regarding Combined oral contraceptive pills but only $25 \%$ of women practiced it in the past. Asking specifically about PPIUCD only $36 \%$ of women had previous knowledge about PPIUCD however only $10 \%$ of women practiced it in the past. All the women were given the knowledge regarding PPIUCD. They were told regarding the benefits of PPIUCD as a contraceptive. After appropriate counselling $18 \%$ of women agreed for insertion of PPIUCD after this delivery (Table 6). Out of 126 women who had previous knowledge of PPIUCD, source of knowledge were evaluated. Maximum women had knowledge regarding PPIUCD by medical personnel (42\%) followed by TV, newspaper, Pemphlet (32\%), friends, neighbours, husband (20\%) (Table 7) 
Table 5: Knowledge and previous practices of different contraceptive methods.

\begin{tabular}{|l|l|l|}
\hline $\begin{array}{l}\text { Family planning } \\
\text { method }\end{array}$ & $\begin{array}{l}\text { Knowledge } \\
(\%)\end{array}$ & $\begin{array}{l}\text { Practice } \\
(\%)\end{array}$ \\
\hline Barrier method & $220(62.85)$ & $100(28.57)$ \\
\hline IUCD & $189(54)$ & $88(25.14)$ \\
\hline Oral contraceptive pills & $160(45.71)$ & $88(25.14)$ \\
\hline Inj DMPA & $105(30)$ & $36(10.28)$ \\
\hline $\begin{array}{l}\text { Non-steroidal } \\
\text { contraceptive pills } \\
\text { (centchroman) }\end{array}$ & $96(27.4)$ & $29(8.28)$ \\
\hline $\begin{array}{l}\text { Female sterilization } \\
\text { Male sterilization }\end{array}$ & $205(58.57 \%)$ & 0 \\
\hline $\begin{array}{l}\text { Emergency } \\
\text { contraceptive }\end{array}$ & $184(52.57 \%)$ & 0 \\
\hline PPIUCD & $126(36.28 \%)$ & $39(11.14 \%)$ \\
\hline
\end{tabular}

Table 6: Patients willing for PPIUCD insertion with this delivery on counselling.

\begin{tabular}{|l|l|l|}
\hline & No. of women & Percentage \\
\hline Yes & 63 & 18 \\
\hline No & 287 & 82 \\
\hline
\end{tabular}

Table 7: Source of previous knowledge of PPIUCD.

\begin{tabular}{|l|l|l|}
\hline Source of knowledge & $\begin{array}{l}\text { No. of } \\
\text { patients }\end{array}$ & Percentage \\
\hline TV, newspapers, pamphlets & 41 & 32.5 \\
\hline Medical personnel & 54 & 42.85 \\
\hline Friends, neighbors, husband & 26 & 20.63 \\
\hline Any other & 5 & 3.96 \\
\hline
\end{tabular}

All the women who consented for PPIUCD insertion after this delivery were evaluated for reasons for acceptance of PPIUCD. Most women had more than one reasons for acceptance. $88.88 \%$ of women preferred it because of reversibility while $76 \%$ women chose it because of long term benefit (Table 8).

Table 8: Reasons for acceptance for PPIUCD.

\begin{tabular}{|l|l|l|}
\hline Reasons & $\begin{array}{l}\text { No. of } \\
\text { women } \\
n=63\end{array}$ & $\begin{array}{l}\text { \% of } \\
\text { women }\end{array}$ \\
\hline Long term & 48 & 76.19 \\
\hline Safe and reliable & 34 & 53.96 \\
\hline Reversible & 56 & 88.88 \\
\hline No remembrance once inserted & 41 & 65.07 \\
\hline No interference with breast feeding & 18 & 28.57 \\
\hline
\end{tabular}

Reasons for denial were also assessed in women who refused for PPIUCD insertion after this delivery. Most common reasons for refusal were family refusal $(80 \%)$ and religious beliefs (69\%) of women had fear of side effects and $44 \%$ of women believed it will interfere with intercourse (Table 9).
Table 9: Reasons for denial.

\begin{tabular}{|l|l|l|}
\hline Reasons & $\begin{array}{l}\text { No. of } \\
\text { women } \\
\text { n=287 }\end{array}$ & $\begin{array}{l}\text { \% of } \\
\text { women }\end{array}$ \\
\hline Fear of expulsion & 108 & 37.63 \\
\hline Fear of perforation infection & 146 & 50.87 \\
\hline Family refusal & 230 & 80.13 \\
\hline Fear of side effects (pain, bleeding) & 165 & 57.49 \\
\hline $\begin{array}{l}\text { Desire of other family planning } \\
\text { method }\end{array}$ & 60 & 20.90 \\
\hline Religious belief & 200 & 69.68 \\
\hline Interferes with intercourse & 127 & 44.25 \\
\hline
\end{tabular}

\section{DISCUSSION}

As the population of our nation is exploding, contraception is the need of hour. Although there are so many contraceptive methods available, an efficacious, long term, cost effective method is desirable in a low resource country as of ours. Also, the postpartum period is very important as women are very receptive for IUCD insertion. This study was conducted to assess the knowledge, attitude and practices of postpartum IUCD. National Family planning programme was started in India in 1956 to address the problem of increasing population. Since then these programmes are operational in India. Despite all the constant efforts unmet need of contraception still exists. ${ }^{7}$

Most women in present study belong to 18-25years age group. In a study by Saroj et al in 2012 majority of women belong to 20-25 years. Awareness level about PPIUCD was highest among age group of 25-35 years, in upper middle class and in women who were educated as postgraduate or more. This was similar to a study done in Egypt by Safwat et al where women with no formal education had acceptance rate of $9.4 \%$ while those with formal education was $19.4 \% .^{8}$ Education plays an important role on contraceptive use as shown in a study done in Zimbabwe. Women who completed secondary education were about twice as likely to use modern contraceptive as compared to other uneducated women. ${ }^{9}$

In present study most commonly used contraceptive method was barrier method $(28.57 \%)$ followed by IUCD and OCPs. Study by Gupta N et al supported present study in which most commonly used contraceptive method was barrier method. Bhasin et al also reported condom as most commonly used contraceptive method. ${ }^{10}$ The aim of present study was to assess the knowledge and practices among antenatal women in an urban area regarding PPIUCD. In present study $36 \%$ of women had knowledge regarding PPIUCD but only $9.7 \%$ women practiced PPIUCD previously. On providing proper knowledge of PPIUCD, $18 \%$ of women gave consent for PPIUCD after this delivery. Although $82 \%$ of women did not give consent at that time however some of them told that they want some time to think about it. Acceptance rate in present study was found to be $18 \%$ which was 
higher than findings in central India (11.9\%), tertiary care centre Indore (10\%), but lower than other studies conducted in Zenana hospital Jaipur (21.8\%), Johrat tertiary care hospital, Assam (36.6\%), Faridabad district, (39\%), Cuttack medical college, Odisha (25.32\%). ${ }^{11-15}$

Present study findings are also supported by Kathpalia SK, Mustafa MS who reported that knowledge and acceptance of postpartum insertion is low among antenatal women. ${ }^{16}$ Present study was also supported by Nigem et al who showed overall contraceptive knowledge of $94 \%$, although $48.4 \%$ women were aware of IUCD and only $21.9 \%$ were aware of PPIUCD. ${ }^{17}$

\section{CONCLUSION}

The study concludes that the antenatal women had poor knowledge regarding PPIUCD. Practices were even worse. This might be attributed to low education, refusal by family especially male partner, and religious beliefs. But once appropriate knowledge and information is provided, attitude gradually changes. Antenatal period and childbirth are definitely a good opportunity for a woman to acquire knowledge regarding contraceptives as they are very receptive towards contraceptives during this period. So, for increasing contraceptive usage people should adopt various kinds of educational and motivational activities. Due attention should be given for enhancing educational level of women and effective PPIUCD counselling should be given during ANC visits to correct misconceptions and wrong beliefs of women regarding PPIUCD insertion.

Funding: No funding sources

Conflict of interest: None declared

Ethical approval: The study was approved by the Institutional Ethics Committee

\section{REFERENCES}

1. Lopez. Farfan JA, Maclel. Martinez M, Velez. Machrro IJ. Vazquez. Estrada L. Application of Mirena during caesarean section. Europe J Contracep, Reproduct Health Care 2010;15(1):165.

2. National Rural Health Mission Ministry of Health and Family Welfare Government of India.JSY. Available http://www.mohfw.nic.in/layout_09 06;.pdf.

3. WHO Medical eligibility criteria for contraceptive use. Geneva. WHO, 2010.

4. Byrd JE, Hyde JS, DeLamater JD, Plant EA. Sexuality during pregnancy and the year postpartum. J Fam Pract.1998; 47(4):305-8.

5. Kappa N, Curtis KM. Review Article Intrauterine Device insertion during the postpartum period: a systemic review. Contraception. 2009;80(4):327-36.
6. Safwat AM, Momen AK, Omar MS, Hossam TS. Acceptability for the Use of Postpartum Intrauterine Contraceptive Devices: Assiut Experience. Med Princ Pract. 2003;12(3):170-5.

7. Mao J. Knowledge, Attitude and Practice of Family Planning. A Study of Tezu Village, Manipur (India). Int J Biological Anthropol. 2006;1(1):5-10.

8. Thomas D, Maluccio J. Fertility, contraceptive choice, and public policy in Zimbabwe. World Bank Econom Rev 1996;10(1):189-222.

9. Choudhary RH. The influence of female education, labour force participation and age at marriage on fertility behavior in Bangladesh. Social Biol 1984;31(1-2):59-74.

10. Bhasin SK, Pant M, Metha M, Kumar S. Prevalence of usages of different contraceptive methods in East Delhi A cross sectional study. IJCM. 2005;30(3):535.

11. Doley RPB. A retrospective study on acceptability and complications of PPIUCD insertion. J Evol Med Dent Sci. 2016;5(31):1631-4.

12. Saroj K, Neha G. Acceptability for the use of postpartum intrauterine contraceptive devices, Zenana Hospital, Jaipur. Int J Sci Res. 2016;5(5):401-9.

13. Kant S, Archana S, Singh AK, Ahamed F, Haldar P. Acceptance rate, probability of follow-up, and expulsion of postpartum intrauterine contraceptive device offered at two primary health centers, North India. J Fam Med Prim Care. 2016;5(4):770-6.

14. Yadav S, Joshi R, Solanki M. Knowledge attitude practice and acceptance of postpartum intrauterine devices among postpartum women in a tertiary care center. Int $\mathbf{J}$ Reprod Contracept Obs Gynecol. 2017;6(4):1507-10.

15. Nayak AK, Jain MK. Experience on Awareness, Acceptability, Safety, Efficacy. Complications and expulsion of postpartum intrauterine contraceptive device insertion. Int J Sci Study. 2017;5(1):207-12.

16. Kathpalia SK, Mustafa MS. Awareness about postpartum insertion of intrauterine device among antenatal cases. Med J Armed Forces India. 2015; 71(3):221-4

17. Nigam A, Ahmad A, Sharma A, Saith P, Batra S. Postpartum Intrauterine Device Refusal in Delhi: Reasons Analyzed. J Obstet Gynecol India. 2018;68(3):208-13.

Cite this article as: Asnani M, Agarwal A, Singh R. Study of knowledge, attitude, practices regarding PPIUCD among antenatal women at a tertiary care centre in Northern India. Int J Reprod Contracept Obstet Gynecol 2019;8:1111-4. 